\title{
Study of Rickets and Osteomalacia in Tibetan Gazelle
}

\author{
Bin Huo ${ }^{1}$ and Xiaoyun Shen ${ }^{1,2,3 *}$ \\ ${ }^{1}$ School of Life Science and Engineering, Southwest University of Science and \\ Technology, Mianyang 621010, China \\ ${ }^{2}$ World Bank Poverty Alleviation Project Office in Guizhou, Southwest China, Guiyang \\ 550004, China. \\ ${ }^{3}$ State Engineering Technology Institute for Karst Desertification Control, Guizhou \\ Normal University, Guiyang 550025, China.
}

\begin{abstract}
A B S T R A C T
Tibetan Gazelle (Procapra picticaudata) are native wildlife to the Qinghai-Tibet Plateau, China. During the past five years, Tibetan Gazelle have been affected by rickets and osteomalacia, characterized by emaciation, growth retardation, lameness, enlargement of the costochondral junctions and abnormal curvature in long bones. The aim of the study was to determine possible relationships between the illness and mineral deficiency. The present result showed that phosphorus contents in soil and forage from affected pastures were significantly lower than those from healthy areas $(P<0.01)$ and the ratio of calcium to phosphorus (Ca:P) in affected herbages was 13.16:1. Phosphorus contents of blood and hair from the affected animals were also significantly lower than those from healthy animals $(P<0.01)$. Serum alkaline phosphatase values from affected Tibetan gazelles were significantly higher than those from healthy ones $(P<0.01)$. Serum inorganic phosphorus contents of affected Tibetan gazelles were about half of those in healthy animals. Oral supplementation of disodium hydrogen phosphate in affected Tibetan gazelles successfully treated the illness. This study demonstrated that the ailment of the Tibetan gazelle was mainly caused by the phosphorus deficiency in forage.
\end{abstract}
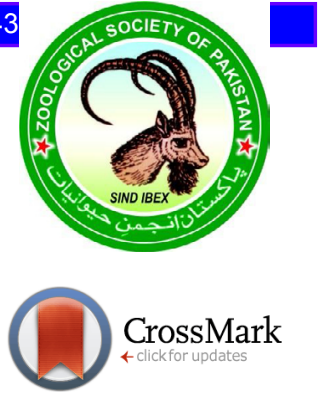

\begin{tabular}{l} 
Article Information \\
Received 01 September 2019 \\
Revised 24 October 2019 \\
Accepted 30 October 2019 \\
Available online 14 May 2020 \\
Authors' Contribution \\
\hline BH and XS designed and performed \\
the study. BH did statistical analysis \\
and wrote the manuscript. XS \\
provided financial support and edited \\
the paper. \\
Key words \\
Tibetan gazelle, The Qinghai-Tibetan \\
Plateau, Rickets, Osteomalacia, \\
Phosphorus deficiency
\end{tabular}

\section{INTRODUCTION}

$\mathrm{T}$ he Tibetan Gazelle (Procapra picticaudata) is an important wild ungulate in the Qinghai-Tibetan Plateau, where it lives in the ecotones between the steppe and desert around Qinghai Lake (Liu and Jiang, 2004; Shen, 2009). It has been classified as critically endangered by the species survival commission of the world conservation union and numbers fewer than 2000 individuals (Shen et al., 2018). During the past five years, the Tibetan gazelle has been affected by rickets and osteomalacia, characterized by emaciation, growth retardation, lameness, muscular relaxation, enlargement of costochondral junctions, stiffness of extremities, and abnormal curvature in long bones, with the most severe cases resulting in permanent recumbency and eventual death. Based on clinical and epidemiological data, we suspected that the sickness may have been associated with mineral deficiency.

This illness had been observed throughout the years with peak incidence occurring between June and October. In severe areas, $28.67 \%$ of the Tibetan gazelle population

\footnotetext{
* Corresponding author: kjxyshenxy@163.com 0030-9923/2020/0005-1751 \$9.00/0

Copyright 2020 Zoological Society of Pakistan
}

were affected and the mortality reached $40.00 \%$. The sickness mainly occurred in mature females and calves. Similar syndromes have been reported in yaks (Shen et al., 2012), cattle (Shupe, 1988), water buffaloes (Heuer and Bode, 1998), pigs (Pullar, 2010), dogs (Dammrich, 1968), camels (Liu, 2005), Speke's gazelle (Gazella spekei) (Martha et al., 2001), Mongolian gazelle (Procapra gutturosa) (Nihat et al., 2002) and Guizhou semi-fine wool sheep (Shen et al., 2014), all of which are related to mineral or vitamin D deficiency. However, there is no available information about this illness affecting the Tibetan gazelle.

The aim of the study was to investigate any relationship between the observed sickness and possible mineral deficiency.

\section{MATERIALS AND METHODS}

\section{Studied areas}

The studied area is located in the Qinghai Lake Watershed in the Qinghai-Tibetan Plateau (36 $57^{\circ}-37^{\circ} 49^{\prime}$ $\mathrm{N}, 101^{\circ} 58^{\prime}-102^{\circ} 47^{\prime} \mathrm{E}$ ), at an average elevation of 3,200 $\mathrm{m}$ above sea level. The mean annual temperature is $1.1^{\circ} \mathrm{C}$, with the minimum temperature $\left(-41^{\circ} \mathrm{C}\right)$ in January and the maximum temperature $\left(27^{\circ} \mathrm{C}\right)$ in July. Annual precipitation varies from 350 to $450 \mathrm{~mm}$ and most rain falls between 
June and September (Fig. 1). June to September is the plant growing season and steppe and alpine meadow are the major vegetation types, with vegetation dominated by desert wormwood (Artemisia desertorum), dilled wormwood (Artemisia anethifolia), shining spear grass (Achnatherum splendens), Moorcraft's sedge (Carex mooscroftii), purple needlegrass (Stipa purpurea) and Chinese iris (Iris lactea). Most of the plants are herbaceous and good food resources for the Tibetan gazelle (Fig. 1).

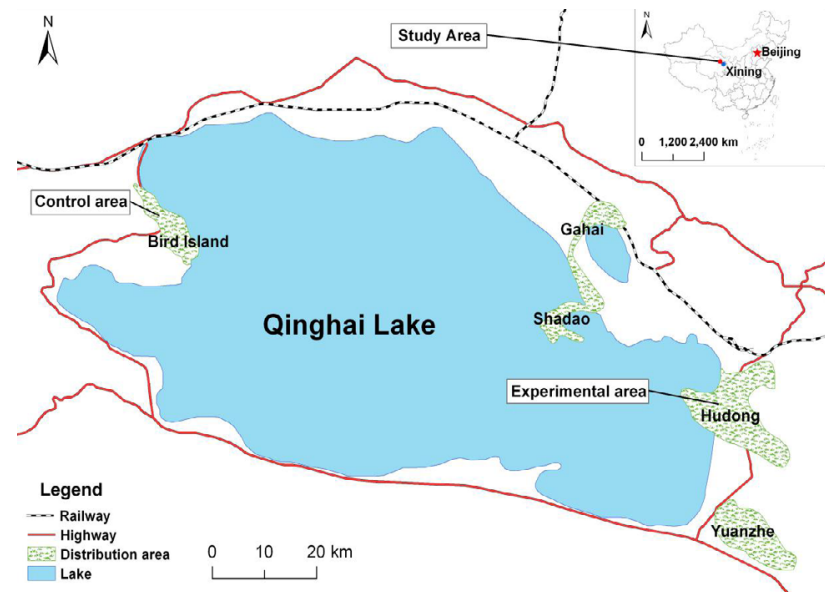

Fig. 1. Studied area.

\section{Epidemiological investigation}

A detailed investigation on the epidemiology of the illness in Tibetan gazells was carried out in the affected pastoral grassland. Data collected included the ecological conditions and the character, history, incidence and regularity of the illness. Clinical signs were recorded by direct observation of gazelle activity on the pastoral grassland.

\section{Experimental animals}

From the $20^{\text {th }}$ to the $25^{\text {th }}$ July 2017 , fifteen Tibetan gazelles with estimated ages between three and 48 months were selected for the following studies, of which 10 were from affected pasture in the eastern part of the Qinghai Lake Watershed in the Qinghai-Tibetan Plateau, China $\left(36^{\circ} 58^{\prime} \mathrm{N}, 101^{\circ} 59^{\prime} \mathrm{E}\right)$. All 10 of these animals showed obvious clinical signs including lameness, weakness, muscular relaxation, stiffness of extremities, and abnormal curvature in long bones. The other five Tibetan gazelles were selected from healthy pastures in the Qinghai Lake National Nature Reserve in the Qinghai-Tibetan Plateau, China $\left(37^{\circ} 18^{\prime} \mathrm{N}, 102^{\circ} 13^{\prime} \mathrm{E}\right)$, where morbidity and mortality had not been reported and clinical examination showed that these animals were of good health (the control group). The affected and healthy Tibetan gazelles were captured using large nylon nets in pastures of herdsmen separated by grassland fences and released into specialized fenced areas in local grasslands to free graze. This area had a $2 \mathrm{~m}$ high fence and the area was about 120 square meters each one. Additionally, seven Tibetan gazelle corpses were collected in the affected pastures from May 21 to August 24, 2017 for routine postmortem examination by visual assessment. These corpses were found by local herdsmen and the time of death varied from one to three days according to herdsman narrative and visual assessment. The affected and healthy pasture locations were about 200 km apart.

\section{Sample collection}

On July 15 2017, 10 herbage samples were collected from five affected pastoral grasslands in the eastern part of the Qinghai Lake Watershed (36 $58^{\prime} \mathrm{N}, 101^{\circ} 59^{\prime} \mathrm{E}$ ). Ten herbage samples were also collected from the healthy rangeland in the Qinghai Lake National Nature Reserve, China $\left(37^{\circ} 18^{\prime} \mathrm{N}, 102^{\circ} 13^{\prime} \mathrm{E}\right)$. To reduce soil contamination, herbage samples were cut $1 \mathrm{~cm}$ above the ground level (Huo et al., 2010). At the same location, twenty soil samples up to $20 \mathrm{~cm}$ deep were taken from the affected and healthy pastures, using a $30 \mathrm{~mm}$ diameter cylindrical corer in affected and healthy pastoral grassland. Each soil sample was composed of four soil cores collected at the site. The soil and herbage samples were dried at $80{ }^{\circ} \mathrm{C}$ for $48 \mathrm{~h}$ and passed through a two mm sieve.

On July 25 2017, hair samples were taken from the neck of the Tibetan gazelle, each sample was individually washed with shampoo and then rinsed five times with distilled water, degreased and kept on silica gel in a desiccator until analyzed (Salmela et al., 1981). Blood samples of the selected Tibetan gazelle were collected from the jugular vein, using trace mineral-free vacutainer tubes and $1 \%$ sodium heparin as anticoagulant for hematological examination and mineral analysis. Serum samples were separated by centrifugation at $12,000 \mathrm{rpm}$ for $10 \mathrm{~min}$ (Shen et al., 2012), chilled at the collection site and then transported to the animal nutrition laboratory at Southwest University of Science and Technology for further preparation and analysis.

\section{Hematological examination}

Hemoglobin $(\mathrm{Hb})$, packed cell volume (PCV), red blood cell (RBC), white blood cell (WBC), mean corpuscular hemoglobin $(\mathrm{MCH})$, mean corpuscular hemoglobin (MCHC), mean corpuscular volume (MCV), neutrophil, lymphocyte, eosinophil, basophil and monocyte numbers were each determined using an automated hematology analyzer (SF-3000, Sysmex-Toa Medical Electronic, Kobe, Japan). 
Analysis of biochemical parameters

Serum total antioxidant capacity (T-AOC), glutathione peroxidase (GSH-Px), superoxide dismutase (SOD), catalase (CAT), malondialdehyde (MDA) were determined using commercial test kits (Nanjing Jiancheng Bio-Engineering Institute, China). Serum ceruloplasmin (Cp), lactate dehydrogenase (LDH), aspartate aminotransferase (AST), alanine aminotransferase (ALT), alkaline phosphatase (AKP), $\gamma$-glutamyl transferase $(\gamma$-GT), creatinine (CRT), cholesterol (Chol), blood urea nitrogen (BUN), glutathione peroxidase (GSH-Px), sodium $(\mathrm{Na})$, potassium $(\mathrm{K})$, magnesium $(\mathrm{Mg})$, calcium $(\mathrm{Ca})$ and inorganic phosphorus (IP) were determined on an automatic analyzer (SF-1, Shanghai Medical Apparatus and Instruments Factory, Shanghai, China). Serum 25-OH vitamin D was measured using ClinRep ${ }^{\circledR}$ HPLC Complete Kit (Recipe Germany). Serum electrophoretic studies of total protein (TP), albumin (ALB) and globulin (GLB) were performed on cellulose acetate (Shen et al., 2006). All serum biochemical values were measured at $20^{\circ} \mathrm{C}$ (Yuan et al., 2011).

\section{Analysis of mineral content}

Microwave digestion heats the digestion liquid in the closed container and each sample was dissolved in the high temperature pressurization. The soil, foliage and animal tissues samples were heated with nitric acid and perchloric acid (4:1) mixture to dissolve the sample. Levels of copper $(\mathrm{Cu})$, iron $(\mathrm{Fe})$, manganese $(\mathrm{Mn})$, cadmium $(\mathrm{Cd})$, lead $(\mathrm{Pb})$, cobalt $(\mathrm{Co})$ and calcium $(\mathrm{Ca})$ were determined using a Perkin-Elmer AAS5000 atomic absorption spectrophotometer (Perkin-Elmer, Norwalk, Connecticut, USA). Molybdenum (Mo) concentration was measured using flameless atomic absorption spectrophotometry (Perkin-Elmer 3030 graphite furnace with a Zeeman background correction) (Shen et al., 2012). Phosphorus (P) concentrations were determined by spectrophotometry (Shen et al., 2014). Fluorine (F) concentration was measured using ion chromatography (Metrohm MIC-7 advanced, Switzerland). The accuracy of the analytical levels were checked by reference to certified levels of elements in the National Bureau of Standards (NBS) (bovine liver SRM 1577a) (Huo et al., 2010).

\section{Treatment response trial}

Ten affected Tibetan gazelles were selected from affected pasture in the Hudong area of the Qinghai Lake Watershed for a treatment response trial. Five affected Tibetan gazelles (two calves and three adult females) were given disodium hydrogen phosphate $\left(\mathrm{Na}_{2} \mathrm{HPO}_{4}\right)$ orally at a dose of $65 \mathrm{~g}$ per animal and grazed on affected fenced pastoral grassland. The treatment was repeated once a week between August and October 2017. The other five affected
Tibetan gazelles grazed on the same area without any treatment and clinical signs were recorded by observation.

\section{Statistical analyses}

Data were analyzed using the Statistical Package for the Social Sciences (SPSS, version 23.0, Inc., Chicago, Illinois, USA), and presented in the form of mean \pm standard error (SE). Significant differences between groups were assessed using Student's $t$-test with least significant differences of $1 \%(P<0.01)$ or $5 \%(P<0.05)$.

\section{RESULTS}

\section{Epidemiology findings}

The illness mainly occurred in calves and mature females throughout the year, with a peak incidence between July and October. Pregnant females were most commonly affected by the ailment. The clinical signs were less obvious in mature males. In severe areas, $28.65 \%$ (53/185) of Tibetan gazelles were affected and the mortality reached $43.40 \%$ (23/53). Besides the symptoms described above, long bones of the affected Tibetan gazelles were broken frequently without apparent stress. The respiratory rate, body temperature, and heart rate of affected Tibetan gazelles were normal (Table I). On examination, the extremities were flexed because of the relaxation of the joint ligaments, resulting in an abnormal posture, including a heel-based stance. The hooves appeared dry and turned back, causing difficulty walking and standing.

\section{Autopsy findings}

Almost all bones, particularly the scapula, mandible, ilium, hip bone and ribs were affected. The affected bones were brittle, porous, light, susceptible to fracturing, and easily cut and sawn. The marrow cavity was enlarged and extended into the epiphysis and the cortex was spongy, thin and soft. Spontaneous fractures frequently occurred in pelvises and ribs of affected Tibetan gazelles and joints were enlarged with bowing of long bones and broadening of the epiphyses. Irregular ulcers were sometime seen on the cartilage surface of the affected joints. Flattening of the humeral head and separation of articular cartilage occurred along with segmental thickening of the physis, thickened metaphyseal trabeculae, and thickened cortices. Tongues of cartilage extended into the metaphysis of costochondral junction in costochondral junction. No bacterial infections were found.

\section{Mineral concentrations}

Contents of phosphorus in the soil and herbage in the affected pastoral grassland were significantly lower than those from healthy pasture $(P<0.01)$ (Table II). 
Table I. Results of the clinical examination in affected Tibetan gazelles.

\begin{tabular}{lllll}
\hline Characteristic & Males (5) & Non-pregnant (5) & Pregnant (5) $^{\mathbf{a}}$ & Calves (5) $^{\mathbf{a}}$ \\
\hline Temperature $\left({ }^{\circ} \mathrm{C}\right)$ & $38.22 \pm 0.03$ & $38.15 \pm 0.02$ & $38.13 \pm 0.01$ & $38.86 \pm 0.03$ \\
Heart rate (beats/min) & $56.31 \pm 1.96$ & $57.67 \pm 1.67$ & $57.37 \pm 1.75$ & $59.98 \pm 1.93$ \\
Respiratory rate (breaths/min) & $18.39 \pm 1.27$ & $18.32 \pm 1.51$ & $18.29 \pm 1.53$ & $19.37 \pm 1.35$ \\
\hline
\end{tabular}

${ }^{a}$ Number of samples.

Table II. Mineral contents in soil and forage samples.

\begin{tabular}{|c|c|c|c|c|}
\hline \multirow[t]{2}{*}{ Elements } & \multicolumn{2}{|c|}{ Soil } & \multicolumn{2}{|c|}{ Forage } \\
\hline & Affected meadow & Healthy meadow & Affected meadow & Healthy meadow \\
\hline $\mathrm{Cu}(\mathrm{mg} / \mathrm{kg})$ & $15.63 \pm 1.52$ & $15.75 \pm 1.51$ & $6.53 \pm 0.57$ & $6.72 \pm 0.69$ \\
\hline Mo $(\mathrm{mg} / \mathrm{kg})$ & $1.17 \pm 0.21$ & $1.15 \pm 0.23$ & $1.17 \pm 0.15$ & $1.12 \pm 0.11$ \\
\hline $\mathrm{Fe}(\mathrm{mg} / \mathrm{kg})$ & $4235.35 \pm 27.56$ & $4272.67 \pm 23.83$ & $336.25 \pm 5.78$ & $332.29 \pm 6.37$ \\
\hline $\operatorname{Mn}(\mathrm{mg} / \mathrm{kg})$ & $57.36 \pm 6.53$ & $58.17 \pm 5.26$ & $12.37 \pm 1.73$ & $12.35 \pm 1.45$ \\
\hline $\mathrm{Co}(\mathrm{mg} / \mathrm{kg})$ & $5.76 \pm 0.51$ & $5.36 \pm 0.55$ & $1.17 \pm 0.08$ & $1.13 \pm 0.07$ \\
\hline $\mathrm{F}(\mathrm{mg} / \mathrm{kg})$ & $21.71 \pm 2.83$ & $21.25 \pm 2.37$ & $13.53 \pm 2.78$ & $14.79 \pm 2.37$ \\
\hline $\mathrm{Ca}(\mathrm{mg} / \mathrm{kg})$ & $12528.35 \pm 67.67$ & $12717.67 \pm 69.83$ & $2779.87 \pm 27.67$ & $2787.39 \pm 22.58$ \\
\hline $\mathrm{P}(\mathrm{mg} / \mathrm{kg})$ & $31.87 \pm 2.16^{\mathrm{a}}$ & $777.77 \pm 7.78$ & $211.28 \pm 13.35^{\mathrm{a}}$ & $1349.68 \pm 19.16$ \\
\hline $\mathrm{Ca}: \mathrm{P}$ & 424.49:1 & $16.35: 1$ & 13.16:1 & $2.07: 1$ \\
\hline
\end{tabular}

$\mathrm{Cu}$, copper; Mo, molybdenum; Fe, iron; Mn, manganese; $\mathrm{Co}$, cobalt; $\mathrm{F}$, fluorine; $\mathrm{Ca}$, calcium; $\mathrm{P}$, phosphorus. ${ }^{\mathrm{a}}$ Results between the affected and healthy pastures were greatly different $(P<0.01)$.

Table III. Mineral element contents of blood and wool in Tibetan gazelles.

\begin{tabular}{|c|c|c|c|c|}
\hline \multirow[t]{2}{*}{ Elements } & \multicolumn{2}{|c|}{ Blood } & \multicolumn{2}{|c|}{ Hair } \\
\hline & Affected animals & Healthy animals & Affected animals & Healthy animals \\
\hline $\mathrm{Cu}(\mathrm{mg} / \mathrm{kg})$ & $0.78 \pm 0.13$ & $0.77 \pm 0.13$ & $5.23 \pm 0.33$ & $5.29 \pm 0.37$ \\
\hline $\operatorname{Mo}(\mathrm{mg} / \mathrm{kg})$ & $0.32 \pm 0.03$ & $0.33 \pm 0.02$ & $0.38 \pm 0.06$ & $0.39 \pm 0.04$ \\
\hline $\mathrm{Fe}(\mathrm{mg} / \mathrm{kg})$ & $512.67 \pm 22.38$ & $513 \pm 23.47$ & $353.79 \pm 25.72$ & $346.67 \pm 15.32$ \\
\hline $\operatorname{Mn}(\mathrm{mg} / \mathrm{kg})$ & $0.53 \pm 0.08$ & $0.54 \pm 0.05$ & $5.47 \pm 0.36$ & $5.43 \pm 0.37$ \\
\hline $\mathrm{Co}(\mathrm{mg} / \mathrm{kg})$ & $0.56 \pm 0.03$ & $0.54 \pm 0.05$ & $1.03 \pm 0.06$ & $0.98 \pm 0.03$ \\
\hline $\mathrm{F}(\mathrm{mg} / \mathrm{kg})$ & $16.76 \pm 2.37$ & $15.27 \pm 1.17$ & $18.99 \pm 2.78$ & $18.89 \pm 3.32$ \\
\hline $\mathrm{Ca}(\mathrm{mg} / \mathrm{kg})$ & $128.76 \pm 11.47$ & $129.76 \pm 12.36$ & $1739.76 \pm 11.87$ & $1797.56 \pm 17.63$ \\
\hline $\mathrm{P}(\mathrm{mg} / \mathrm{kg})$ & $113.76 \pm 14.89^{\mathrm{a}}$ & $263.76 \pm 11.27$ & $63.33 \pm 9.65^{\mathrm{a}}$ & $127.71 \pm 13.76$ \\
\hline
\end{tabular}

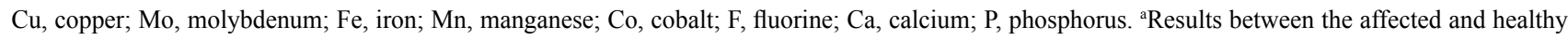
animals were greatly different $(P<0.01)$.

The Ca: P ratio in herbage of the affected pastoral grassland was 13.16:1. Other mineral contents were within normal range. Phosphorus contents of the hair and blood samples from affected Tibetan gazelles were about half of healthy animals (Tables II and III).

Hematological and biochemical values

There were no marked differences in serum $25-\mathrm{OH}$ vitamin $\mathrm{D}$ between the healthy and affected animals. Serum creatinine, lactate dehydrogenase and alkaline phosphatase of affected Tibetan gazelles were significantly higher than those in healthy animals $(P<0.01)$, while IP values were about half of those in the healthy Tibetan gazelle. The alkaline phosphatase level of the affected Tibetan gazelle were double that of the healthy Tibetan gazelle (Tables IV and V). Serum $\alpha$-globulin and $\beta$-globulin of affected 
Tibetan gazelles were significantly higher than those of the healthy animals $(P<0.01)$ and serum $\gamma$-globulin of the affected Tibetan gazelle were significantly lower $(P<$ 0.01 ) (Table VI). There were no significant differences in other biochemical values.

Table IV. Hematological parameters in Tibetan gazelles.

\begin{tabular}{lll}
\hline $\begin{array}{l}\text { Hematological } \\
\text { parameters }\end{array}$ & $\begin{array}{l}\text { Affected } \\
\text { animals }\end{array}$ & $\begin{array}{l}\text { Healthy } \\
\text { animals }\end{array}$ \\
\hline $\mathrm{Hb}(\mathrm{g} / \mathrm{L})$ & $117.67 \pm 7.13$ & $118.35 \pm 8.67$ \\
$\mathrm{RBC}\left(10^{12} / \mathrm{L}\right)$ & $6.73 \pm 0.23$ & $6.97 \pm 0.27$ \\
$\mathrm{PCV} \mathrm{( \% )}$ & $42.13 \pm 3.52$ & $42.37 \pm 3.32$ \\
$\mathrm{MCV}(\mathrm{fl})$ & $57.62 \pm 4.13$ & $56.63 \pm 4.36$ \\
$\mathrm{MCH}(\mathrm{pg})$ & $16.94 \pm 1.37$ & $17.78 \pm 1.41$ \\
$\mathrm{MCHC}(\%)$ & $24.16 \pm 2.13$ & $23.95 \pm 2.14$ \\
$\mathrm{WBC}\left(10^{9} / \mathrm{L}\right)$ & $11.77 \pm 0.62$ & $11.33 \pm 0.51$ \\
$\mathrm{Neutrophils} \mathrm{( \% )}$ & $64.91 \pm 3.87$ & $64.58 \pm 3.27$ \\
Lymphocytes (\%) & $23.59 \pm 1.31$ & $24.17 \pm 1.17$ \\
Monocytes (\%) & $0.79 \pm 0.04$ & $0.77 \pm 0.05$ \\
Eosinophils (\%) & $6.47 \pm 2.48$ & $6.56 \pm 2.35$ \\
Basophils (\%) & $0.58 \pm 0.03$ & $0.59 \pm 0.02$ \\
\hline
\end{tabular}

$\mathrm{Hb}$, hemoglobin; RBC, red blood cell; $\mathrm{PCV}$, packed cell volume; $\mathrm{MCH}$, mean corpuscular hemoglobin; $\mathrm{MCHC}$, mean corpuscular hemoglobin concentration; $\mathrm{MCV}$, mean corpuscular volume; $\mathrm{WBC}$, white blood cell.

\section{Treatment and prevention}

Affected Tibetan gazelles treated with dibasic sodium phosphate recovered within 10 to $20 \mathrm{~d}$. Appetite improved and signs of lameness in most treated animals improved within 20 to $25 \mathrm{~d}$ after treatment, but foreleg deformation recovered slowly and required prolonged treatment. Calves and mature females were more vulnerable than males in the treated and untreated animal. Five treated Tibetan gazelles totally survived. Of the five untreated Tibetan gazelles, two calves and one mature female survived and one mature female and one calf died.

\section{DISCUSSION}

Mineral element related illnesses of livestock, wildlife and humans have been widely reported. Huang and Chen (2002) reported the effects of copper and sulfur deficiency in herbage on Tibet sheep in Gansu Province in China. Shen et al. (2006) reported an illness of yaks in the Qinhai-Tibetan Plateau, which was related to copper deficiency caused by high molybdenum in forage. Shen et al. (2010) reported an illness of Tibetan Gazelle due to copper deficiency caused by high sulfur levels in forage in the Qinhai Lake Watershed, China. Yuan et al. (2011) reported copper deficiency of Guizhou semi-fine wool sheep in Guizhou Province of China, mainly due to high sulfur and molybdenum levels in herbage. Martha et al. (2001) reported osteomalacia of Speke's gazelle caused by vitamin D deficiency. Nihat et al. (2002) reported rickets of Mongolian gazelle, related to vitamin D deficiency. Shen et al. (2014) reported phosphorus deficiency in sheep. Burk et al. (2015) reported an illness of some patients to selenium deficiency. The main signs of these illnesses included appetite loss, emaciation, growth retardation, pica, anemia, necrosis of skeletal muscle and weight loss. Compared with the sickness above, the illness reported in this study occurred in different locations, had different characteristics, involved different animals and different nutritional deficiencies to other studies and is the first report of such an illness in the Tibetan gazelle.

Table V. Serum biochemical parameters in Tibetan gazelles.

\begin{tabular}{|c|c|c|}
\hline Biochemical parameters & $\begin{array}{l}\text { Affected } \\
\text { animals }\end{array}$ & $\begin{array}{l}\text { Healthy } \\
\text { animals }\end{array}$ \\
\hline T-AOC (U/mL) & $4.21 \pm 0.12$ & $4.39 \pm 0.13$ \\
\hline GSH-Px $(\mathrm{U} / \mathrm{mL})$ & $427.67 \pm 8.56$ & $429.57 \pm 9.96$ \\
\hline $\mathrm{SOD}(\mathrm{U} / \mathrm{mL})$ & $151.37 \pm 5.73$ & $159.66 \pm 9.32$ \\
\hline CAT (U/mL) & $16.63 \pm 1.25$ & $16.92 \pm 1.63$ \\
\hline $\operatorname{MDA}(\mathrm{nmol} / \mathrm{mL})$ & $3.77 \pm 0.38$ & $3.66 \pm 0.19$ \\
\hline $\operatorname{AST}(\mathrm{U} / \mathrm{L})$ & $12.76 \pm 1.22$ & $12.98 \pm 1.37$ \\
\hline $\operatorname{ALT}(\mathrm{U} / \mathrm{L})$ & $35.77 \pm 3.35$ & $36.73 \pm 3.57$ \\
\hline $\mathrm{Cp}(\mathrm{mg} / \mathrm{dL})$ & $52.76 \pm 3.17$ & $51.97 \pm 3.27$ \\
\hline $\mathrm{LDH}(\mu \mathrm{moL} / \mathrm{L})$ & $3.96 \pm 0.58^{\mathrm{a}}$ & $5.63 \pm 0.59$ \\
\hline$\gamma-\mathrm{GT}(\mathrm{IU} / \mathrm{L})$ & $26.37 \pm 3.28$ & $27.29 \pm 3.11$ \\
\hline $\mathrm{AKP}(\mathrm{IU} / \mathrm{L})$ & $121.76 \pm 7.83^{\mathrm{a}}$ & $51.28 \pm 3.56$ \\
\hline $\mathrm{CRT}(\mu \mathrm{moL} / \mathrm{L})$ & $149.56 \pm 7.67^{\mathrm{a}}$ & $97.74 \pm 5.27$ \\
\hline $\operatorname{Mg}(\mathrm{mmol} / \mathrm{L})$ & $0.87 \pm 0.12$ & $0.89 \pm 0.13$ \\
\hline $\mathrm{K}(\mathrm{mmol} / \mathrm{L})$ & $4.49 \pm 0.31$ & $4.33 \pm 0.42$ \\
\hline $\mathrm{Na}(\mathrm{mmol} / \mathrm{L})$ & $137.31 \pm 5.39$ & $138.26 \pm 6.37$ \\
\hline $\mathrm{Ca}(\mathrm{mmoL} / \mathrm{L})$ & $2.77 \pm 0.21$ & $2.76 \pm 0.25$ \\
\hline IP (mmoL/L) & $1.35 \pm 0.02^{\mathrm{a}}$ & $2.79 \pm 0.03$ \\
\hline BUN (mmoL/L) & $6.97 \pm 0.37$ & $6.87 \pm 0.76$ \\
\hline Chol (mmoL/L) & $2.97 \pm 0.21$ & $2.89 \pm 0.26$ \\
\hline $25-\mathrm{OH}$ vitamin $\mathrm{D}(\mathrm{ng} / \mathrm{mL})$ & $32.37 \pm 2.38$ & $31.83 \pm 3.13$ \\
\hline
\end{tabular}

T-AOC, total antioxidant capacity; GSH-Px, glutathione peroxidase; SOD, superoxide dismutase; CAT, catalase; MDA, malondialdehyde; AST, aspartate aminotransferase; ALT, alanine aminotransferase; $\mathrm{Cp}$, ceruloplasmin; LDH, lactate dehydrogenase; $\gamma$-GT, $\gamma$-glutamyl transferase; AKP, alkaline phosphatase; CRT, creatinine; $\mathrm{Mg}$, magnesium; $\mathrm{K}$, potassium; Na, sodium; Ca, calcium; IP, inorganic phosphorus; BUN, blood urea nitrogen; Chol, cholesterol. 
Table VI. Serum protein parameters in Tibetan gazelles.

\begin{tabular}{lll}
\hline Protein parameters & Affected animals & Healthy animals \\
\hline Total protein $(\mathrm{g} / \mathrm{L})$ & $62.13 \pm 3.22$ & $68.37 \pm 3.32$ \\
Albumin $(\mathrm{g} / \mathrm{L})$ & $44.75 \pm 3.77$ & $45.95 \pm 2.79$ \\
$\alpha-G l o b u l i n(\mathrm{~g} / \mathrm{L})$ & $3.72 \pm 0.51$ & $3.97 \pm 0.76$ \\
$\beta$-Globulin $(\mathrm{g} / \mathrm{L})$ & $3.83 \pm 0.62^{\mathrm{a}}$ & $4.79 \pm 0.87$ \\
$\gamma$-Globulin $(\mathrm{g} / \mathrm{L})$ & $9.83 \pm 0.73^{\mathrm{a}}$ & $13.66 \pm 1.28$ \\
$\mathrm{~A} / \mathrm{G}$ & $2.57 \pm 0.35$ & $2.05 \pm 0.33$ \\
\hline
\end{tabular}

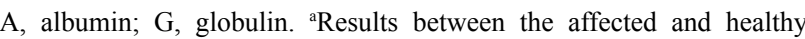
animals were greatly different $(P<0.01)$.

In this study, clinical observation and epidemiological investigation indicated that the Tibetan gazelle suffered a mineral metabolic ailment associated with phosphorus deficiency. The result showed that the phosphorus content of the soil and forage in affected pastures was significantly lower than in normal healthy pastures. Phosphorus contents of blood and hair from affected Tibetan gazelles were also significantly lower and serum alkaline phosphatase values were markedly higher than those of healthy Tibetan gazelles. Results from this study were consistent with the response criteria in phosphorus deficiency illness of camels, sheep, pigs, dogs, and yaks (Dammrich, 1968; Liu, 2005; Scott et al., 1984; Scott et al., 1995; Shen et al., 2012). The oral supplement of dibasic sodium phosphate appeared to cure the illness successfully, proving that the sickness affecting the Tibetan gazelle was related to the phosphorus deficiency in herbage.

For many forage species, the period with relatively high phosphorus contents $(>0.3 \% \mathrm{DM})$ available to wildlife is relatively short (Heuer and Bode, 1998; Field et al., 1985; Suttle, 2010). In most years, mature herbage contains phosphorus lower than $0.15 \%$ (Wang and Liu, 2004; Scott and Buchan, 1985). Adequate foliage phosphorus requirements for ruminants are greater than $0.005 \%$ in soils and higher than $0.3 \%$ in herbage (Karn, 2001; Suttle, 2010; Vromman et al., 2017), whereas in this study, phosphorus contents of the soil and herbage in the affected pasture were $0.0032 \%$ and $0.021 \%$, respectively.

Among the factors influencing phosphorus and calcium utilization metabolism, a mean Ca: $\mathrm{P}$ ratio of $1: 1$ to $2: 1$ is recommended for proper utilization of mineral elements by animals (Beleidy et al., 2017; Maduell et al., 2005; Shupe, 1988; Wang et al., 1995). Dietary Ca:P ratios below $1: 1$ or above 7:1 will adversely affect growth and feed efficiency of animals (Braithwaite, 1985; Zhang et al., 2017). In the present study, the Ca:P ratio in forage from the healthy pasture was $2: 1$, but the $\mathrm{Ca}: \mathrm{P}$ ratio in herbage from the affected pastoral grassland was 13.16:1, which should have had a detrimental effect on the calcium and phosphorus metabolism of the Tibetan gazelle in the affected area. To prevent phosphorus deficiency in livestock and wildlife, oral supplement of bone meal, phosphate and mineral mixtures is recommended (Liu, 2005; Scott and Buchan, 1987).

A number of response criteria have been used to evaluate the phosphorus status of animals, including serum values of phosphorus, calcium, and alkaline phosphatase (Sakuma et al., 2018). A marked hypophosphatemia is also a good indicator of a severe phosphorus deficiency, even if serum contents of calcium are healthy. Blood phosphorus levels are not a good indicator for phosphorus status, because such values can be normal for an extended period after animals have been exposed to serious dietary phosphorus deficiency (Mazouri et al., 2017; Shen et al., 2014). Some studies have shown that diet induced phosphorus deficiency increased serum calcium concentrations in goats and rats (Yolanda et al., 1996; Härter et al., 2016). This effect can be explained by a phosphorus deficiency which induces an increase in the efficiency of intestinal calcium absorption, decreased bone formation, increased bone resorption and increased renal calcium reabsorption (Santos et al., 2014). In the current study, the serum calcium concentrations were not significantly different between the healthy and affected Tibetan gazelles. Phosphorus is the second most abundant mineral in an animal and alkaline phosphatase is involved in enzyme processes of bone formation and maintenance. Previous investigations have demonstrated that phosphorus deficiency can induce a variety of functional and structural changes such as muscle weakness, decreased hepatic oxygenation and abnormal liver function (Liao et al., 2017). In this study, serum alkaline phosphatase, lactate dehydrogenase and creatinine activity in the affected Tibetan gazelles were significantly increased, which is consistent with phosphorus deficiency in pigs and cows (Drews et al., 2016; Zhang et al., 2017).

Phosphorus deficiency should be differentiated from chronic fluorosis in mature animals (Kauv, 2017; Ferrier-Pagès et al., 2016). The typical characteristic of fluorine toxicity includes mottling and pitting of teeth and enlargements on the shafts of long bones. In the present study, fluorine contents in soil and herbage were lower than the critical contents of 30 to $40 \mathrm{ppm}$ (Adedokun and Adeol, 2013; Liu et al., 2015; Burk et al., 2015). The fluorine contents in blood and hair were within the healthy range, therefore, the illness of the Tibetan gazelle was not related to fluorosis. The illness of the Tibetan gazelle in Hudong area of the Qinghai Lake Watershed in the Qinghai-Tibetan Plateau is therefore locally nutritional and the metabolic illness is due to phosphorus deficiency in soil and forage. 


\section{ACKNOWLEDGEMENTS}

This work was supported by the National Natural Science Foundation of China (41671041) and the Research Fund for the Doctoral Program of Southwest University of Science and Technology (17zx7146).

\section{Compliance with ethical standards}

Tibetan gazelles in these studies were cared for as outlined in the guide for the care and use of animals in research and teaching consortium (Federation of Animals Science Societies, 2010). Sample collections in animals were approved by Southwest University of Science and Technology in China, Institutional Animal Care and Use Committee (Project A00554) and the Wildlife Conservation Management Bureau of Qinghai Forestry Department (Project 2017-219).

\section{Statement of conflict of interest}

The authors have declared no conflict of interest.

\section{REFERENCES}

Adedokun, S.A. and Adeol, O., 2013. Calcium and phosphorus digestibility: Metabolic limits1. J. Appl. Poult. Res., 22: 600-608. https://doi.org/10.3382/ japr.2013-00740

Beleidy, A.E., Sherbini, S.A.E. and Elgebaly, H.A.F., 2017. Calcium, magnesium and phosphorus deficiency in critically ill children. Egypt. Pediat. Assoc. Gaz., 65: 267-279. https://doi.org/10.1016/j. epag.2017.03.004

Braithwaite, G.D., 1985. Endogenous faecal loss of phosphorus in growing lambs and the calculation of phosphorus requirements. J. agric. Sci., 105: 6772. https://doi.org/10.1017/S0021859600055726

Burk, R.F., Hill, K.E., Motley, A.K., Byrne, D.W. and Norsworthy, B.K., 2015. Selenium deficiency occurs in some patients with moderate to-severe cirrhosis and can be corrected by administration of selenate but not selenomethionine: a randomized controlled trial. Am. J. clin. Nutr., 102: 1126-1133. https://doi.org/10.3945/ajen.115.110932

Dammrich, K., 1968. Osteomalacia in the dog and cat. Deut. Tierarztl. Woch., 75: 64-70.

Drews, J.E., Haese, D. and João, L.K., 2016. Phosphorus on performance, hematological, biochemical, and bone parameters of growing pigs. Cienc. Rural., 46: 1076-1081. https://doi.org/10.1590/0103$8478 \mathrm{cr} 20150132$

Ferrier-Pagès, C., Godinot, C., Angelo, C., Wiedenmann, J. and Grover, R., 2016. Phosphorus metabolism of reef organisms with algal symbionts. Ecol. Monogr., 86: 189-197. https://doi.org/10.1002/ecm.1217

Field, A.C., Williams, J.A. and Dingwall, R.A., 1985. The effect of dietary intake of calcium and dry matter on the absorption and excretion of calcium and phosphorus by growing lambs. $J$. agric. Sci., 105: 237-243. https://doi.org/10.1017/ S0021859600056288

Heuer, C. and Bode, E., 1998. Variation of serum inorganic phosphorus and association with hemoglobinuria and osteomalacia in female water buffaloes in Pakistan. Prev. Vet. Med., 33: 69-81. https://doi.org/10.1016/S0167-5877(97)00064-0

Härter, C.J., Lima, L.D., Castagnino, D.S., Rivera, A.R., Nunes, A.M. and Sousa, S.F., 2016. Mineral metabolism of pregnant goats under feed restriction. Anim. Prod. Sci., 57: 290-300. https:// doi.org/10.1071/AN14471

Huang, Y. and Chen, H., 2002. Studies on the pathogenesis of shimao zheng (fleece-eating) in sheep and goats. Vet. Res. Commun., 25: 631-640.

Huang, Y., 2001. An experimental study on treatment and prevention of shimao zheng (fleece-eating) in sheep and goats in the haizi area of akesai county in China. Vet. Res. Commun., 26: 39-48.

Huo, B., He, J. and Shen, X.Y., 2020. Effects of selenium-deprived habitat on the immune index and antioxidant capacity of Przewalski's gazelle. Biol. Trace Element Res., https://doi.org/10.1007/ s12011-020-02070-6

Karn, J.F., 2001. Phosphorus nutrition of grazing cattle: a review. Anim. Feed Sci. Tech., 89: 133-153. https://doi.org/10.1016/S0377-8401(00)00231-5

Kauv, P., Ayache, S.S., Créange, A. and Chalah, M.A., 2017. Adenosine triphosphate metabolism measured by phosphorus magnetic resonance spectroscopy: A potential biomarker for multiple sclerosis severity. Eur. Neurol., 7: 316-318. https:// doi.org/10.1159/000475496

Liao, Y., Cao, H. and Xia, B., 2017. Changes in trace element contents and morphology in bones of duck exposed to molybdenum or/and cadmium. Biol. Trace. Elem. Res., 175: 449-457. https://doi. org/10.1007/s12011-016-0778-0

Liu, B.W. and Jiang, Z.G., 2004. Dietary overlap between Przewalski's gazelle and domestic sheep in the Qinghai lake region and its implication for rangeland management. J. Wildl. Manage., 68: 223-229. https://doi.org/10.2193/0022-541X(2004 )668[0241:DOBPGA]2.0.CO;2

Liu, S.X., Zhu, W.P., Li, S.J. and Cui, T.X., 2015. The effect of bovine parathyroid hormone withdrawal 
on MC3T3-E1 cell proliferation and phosphorus metabolism. PLoS One, 10: e0120402. https://doi. org/10.1371/journal.pone.0120402

Liu, Z., 2005. Studies on rickets and osteomalacia in bactrian camels (Camelus bactrianus). Vet. J., 169: 444-453. https://doi.org/10.1016/j.tvj1.2004.03.014

Maduell, F., Gorriz, J.L., Pallardo, L.M., Pons, R. and Santiago, C., 2005. Assessment of phosphorus and calcium metabolism and its clinical management in hemodialysis patients in the community of Valencia. J. Nephrol., 18: 739-748.

Martha, A., Weber, D.V.M. and Randall, E., 2001. Hypophosphatemia associated with hypovitaminosis-D in Speke's Gazelles (Gazella Spekei). J. Zoo. Wildl. Med., 32: 379-383. https:// doi.org/10.1638/1042-7260(2001)032[0379:HAWH DI]2.0.CO;2

Mazouri, A., Khosravi, N., Bordbar, A., Khalesi, N., Saboute, M., Taherifard, P., Mirzababaee, M. and Ebrahimi, M., 2017. Does adding intravenous phosphorus to parenteral nutrition has any effects on calcium and phosphorus metabolism and bone mineral content in preterm neonates? Acta med. Iran., 55: 395-398.

Mcglone, J., Ford, S. and Mitloehner, F., 2010. Guide for the care and use of agricultural animals in research and teaching, 3rd Edition. Federation of Animals Science Societies. FASS, Champaign, Illinois. pp. 169.

Nihat, S., Ibrahim, Ç. and Gürbüz, A., 2002. Rickets in a Gazelle: a case report. Turk. J. Vet. Anim. Sci., 26: 415-418.

Pullar, E.M., 2010. Mineral deficiencies in pigs. II. Bone ash estimations as a diagnostic aid in rickets and osteomalacia. Aust. Vet. J., 36: 31-45. https://doi. org/10.1111/j.1751-0813.1960.tb03760.x

Sakuma, M., Suzuki, A., Kikuchi, M. and Arai, H., 2018. Soymilk intake has desirable effects on phosphorus and calcium metabolism. J. clin. Biochem. Nutr., 62: 259-263. https://doi.org/10.3164/jcbn.17-79

Salmela, S., Vuori, E. and Kilpo, J.O., 1981. The effect of washing procedures on trace element content of human hair. Anal. chim. Acta, 125:131-137. https:// doi.org/10.1016/S0003-2670(01)85057-1

Santos, T.T., Walk, C.L., Wilcock, P., 2014. Performance and bone characteristics of growing pigs fed diets marginally deficient in available phosphorus and a novel microbial phytase. Can. J. Anim. Sci., 94: 493497. https://doi.org/10.4141/cjas2013-190

Scott, D. and Buchan, W., 1985. The effect of feeding either roughage or concentrate diets on salivary phosphorus secretion, net intestinal absorption and urinary excretion in the sheep. Q. J. exp. Physiol., 70: 365- 375. https://doi.org/10.1113/expphysiol.1985. sp002922

Scott, D. and Buchan, W., 1987. The effect of feeding either hay or grass diets on salivary phosphorus secretion, net intestinal absorption and on the partition of phosphorus between urine and faeces in the sheep. Q. J. exp. Physiol., 72: 331-338. https:// doi.org/10.1113/expphysiol.1987.sp003078

Scott, D., McLean, A.F. and Buchan, W., 1984. The effect of variation in phosphorus intake on net intestinal phosphorus absorption, salivary phosphorus secretion and pathway of phosphorus excretion in sheep fed roughage diets. Q. J. exp. Physiol., 69: 439-452. https://doi.org/10.1113/expphysiol.1984. sp002830

Scott, D., Rajaratne, A.A.J. and Buchan, W., 1995. Factors affecting faecal endogenous phosphorus loss in the sheep. J. agric. Sci., 124: 145-151. https://doi. org/10.1017/S0021859600071355

Shen, X.Y., Du, G.Z. and Li, H., 2006. Studies of a naturally occurring molybdenum-induced copper deficiency in the yak. Vet. J., 171:352-357. http:// dx.doi.org/10.1016/j.tvj1.2004.11.006

Shen, X.Y., 2009. Forage strategy of Przewalski's gazelle under selenium stress. Acta Ecol. Sin., 29: 27752781.

Shen, X.Y., Li, X. and Zhang, R.D., 2010. Studies of "unsteady gait disease" of the Tibetan gazelle (Procapra picticaudata). J. Wildl. Dis., 46: 560-563. https://doi.org/10.7589/0090-3558-46.2.560

Shen, X.Y. and Zhang, R.D., 2012. Studies on "stiffness of extremities disease" in the yak (Bos mutus). J. Wildl. Dis., 48: 542-547. https://doi.org/10.7589/00903558-48.3.542

Shen, X.Y., Zhang, J.H. and Zhang, R.D., 2014. Studies on phosphorus metabolic disorder in Guizhou semifine wool sheep. PLoS One, 9: e89472. https://doi. org/10.1371/journal.pone.0089472

Shen, X.Y., Huo, B., Min, X.Y., Wu, T., Liao, J.J., Cai, P., Zhang, Y., He, Y.B., Sun, J.Q. and Wu, Y.L., 2018. Assessment of mineral nutrition of forage in the natural habitat of Przewalski's gazelle (Procapra przewalskii). Acta Pratacult. Sin., 27: 108-115.

Shupe, J.L., 1988. Clinical signs and bone change associated with phosphorus deficiency in beef cattle. Am. J. Vet. Res., 49: 1619-1636.

Suttle, N.F., 2010. The mineral nutrition of livestock. $4^{\text {th }}$ ed. CABI Publishing Cambridge, USA, pp. 579. https://doi.org/10.1079/9781845934729.0000

Vromman, D., Martinez, J.P. and Lutts, S., 2017. Phosphorus deficiency modifies as translocation in 
the halophyte plant species atriplex atacamensis. Ecotox. Environ. Safe., 139: 344-351. https://doi. org/10.1016/j.ecoenv.2017.01.049

Wang, J. and Liu, Z., 2004. Veterinary clinical diagnosis. Chinese Agricultural Press, Beijing, China, pp. 373.

Wang, Z., Cao, G., Hu, Z. and Ding, Y., 1995. Mineral element metabolism and animal disease, Shanghai Science-Technology Press, Shanghai, China, pp. 544.

Yolanda, A., Canalejo, A. and Alexis, H., 1996. Direct effect of phosphorus on PTH secretion from whole rat parathyroid glands in vitro. J. Bone Miner. Res., 11: 970-976. https://doi.org/10.1002/jbmr.5650110714 Yuan, R., Li, L.J., Wang, Q.W. and Du, G.Z., 2011. Copper deficiency in Guizhou semi-fine wool sheep on pasture in south west China karst mountain area. Afr. J. Biotechnol., 10: 17043-17048. https://doi. org/10.5897/AJB11.2398

Zhang, Z.W., Bi, M.Y., Yang, J. and Yao, H.D., 2017. Effect of phosphorus deficiency on erythrocytic morphology and function in cows. J. Vet. Sci., 18: 333-340. https://doi.org/10.4142/jvs.2017.18.3.333 